EGU2020-15585

https://doi.org/10.5194/egusphere-egu2020-15585

EGU General Assembly 2020

(c) Author(s) 2021. This work is distributed under

the Creative Commons Attribution 4.0 License.

\title{
Morphology of the Messinian Salinity Crisis surfaces and its related deposits in the Alboran Sea: a continuous Mediterranean-Atlantic connection?
}

\author{
Damien Do Couto ${ }^{1}$, Ferran Estrada ${ }^{2}$, Christian Gorini ${ }^{1}$, Gemma Ercilla ${ }^{2}$, and Jean-Pierre Suc ${ }^{1}$ \\ 'Sorbonne Université, ISTeP, France (damien.do_couto@upmc.fr) \\ ${ }^{2} \mathrm{ICM}, \mathrm{CSIC}$, Barcelona, Spain
}

The Messinian Salinity Crisis (MSC), which affected the Mediterranean region during the latest Miocene, is mainly characterized by the deposition of thick evaporites in central basins and strong fluvial erosion of margins. The subaerial fluvial erosion, known as the Messinian Erosional Surface (MES), is for instance continuously followed from the Gulf of Lions up to $360 \mathrm{~km}$ from the presentday shoreline upstream the Rhône Valley. Short drainage systems limited by high coastal mountain ranges, must have been significantly affected by the Messinian erosion.

The Alboran Sea is similarly characterized by a geographic context and was the first Mediterranean area concerned by connection-disconnection to the Atlantic Ocean during the last millions years. A recent study suggested that the Alboran Sea remained always connected to the Atlantic Ocean during the MSC, being the marine refuge for the Mediterranean taxa.

In this work, we have performed an extensive research of the MES and MSC-related deposits in the Alboran region, both onshore and offshore, integrating outcrop descriptions, supported by new biostratigraphic data and seismic profile analyses. This study leads to an up-to-date geological and morphological map displaying the actual contours and morphology of the MES in the whole Alboran domain. The MES has a subaerial origin and is continuously followed from land to the offshore domain, sealed by post-MSC marine sediments. Both Spanish and Morrocan sides show three different erosive morphologies: downslope trending paleocanyons cut by a large reflooding channel crossing the entire Alboran basin from the Strait of Gibraltar to Algerian Basin, and alongslope terraces. The occurrence of all these striking erosive features with basinal extension questions the hypothesis of the permanent connection with the Atlantic Ocean. 